\title{
Research on the Mode of Generation Rights Trade between Renewable Energy and Self-generation Power Plants Based on Cooperative Game Theory
}

\author{
Xia $\operatorname{Tian}^{1,2}$ \\ 1. North China Electric Power University \\ 2. State Grid Gansu Electric Power Corporation \\ Beijing, China;Lanzhou, China
}

\author{
He Yongxiu $^{1}$, Song Dong ${ }^{1}$, Guang Fengtao ${ }^{1}$ \\ 1. North China Electric Power University \\ School of Economics and Management \\ Beijing, China
}

\begin{abstract}
Under the background of wind and photovoltaic curtailment severely, it is an effective transaction mode to use the generation rights trade between renewable energy and self-generation power plants, which can not only alleviate wind and photovoltaic curtailment, but also can promote renewable energy consumption. Based on the Cooperative Game Theory, this paper studied a kind of transaction mode between self-generation power plants and renewable energy. Taking Gansu Province as an example, this paper analyzed the case of renewable energy and self-generation power plants. By comparing the gains and losses before and after participating in the cooperative game so as to verify the feasibility and validity of the generation rights trade, which can provide a reference for the generation rights trade between renewable energy and self-generation power plants.
\end{abstract}

Keywords-Wind and photovoltaic curtailment; Cooperative Game Theory; Renewable energy; Self-generation power plants; Generation rights trade

\section{INTRODUCTION}

Northwest China is an important renewable energy base. Since 2010, renewable energy in Northwest region has entered into large-scale fast developing stage. By the end of 2015, taking Gansu province as an example, wind power installed capacity has reached $12.52 \mathrm{GW}$, with a high annual growth rate of $68.85 \%$; Photovoltaic power installed capacity is up to $6.1 \mathrm{GW}$, with an annual growth rate of $354.98 \%$. However, at the same time, the problems of lack of electricity demand, the narrow power market and few delivery channels and other issues in the Northwest region, to a certain extent, have restricted the consumption and delivery of renewable energy, resulted in a large number of wastes of resources. For instance, the rate of wind and photovoltaic curtailment has up to $39 \%$ and $31 \%$ respectively in 2015 . Therefore, in order to promote the development of renewable energy orderly, the analysis of generation rights trade between renewable energy and self-generation power plants in the new situation is imminent $[1-3]$

\section{Cooperative Game Theory}

Cooperative Game Theory refers to the campaign with the existence of binding cooperative agreements, emphasizing collective rationality, fairness and efficiency. And only when the distribution of cooperative game is at the same time in line with individual rationality as well as overall rationality, can it turn out to be effective. The allocation strategies of the theory consist of equal allocation strategy, capacity allocation strategy and Shapley Value allocation strategy ${ }^{[4]}$.

\section{A. Equal allocation strategy}

Equal allocation strategy is that all the participants bisect the entire league's revenue equally, which is shown in the formula:

$$
x_{f}=x_{w}=x_{s}=\frac{v(f, w, s)}{3}
$$

where ${ }^{x_{f}}$ is the benefits of self-generation power plants in the league, $x_{w}$ is the benefits of wind power station in the league, $x_{s}$ is the benefits of photovoltaic power station in the league, $v(f, w, s)$ is the benefits of the entire alliance.

\section{B. Capacity allocation strategy}

Capacity allocation strategy distributes the benefits based on the proportion of every participant's capacity to the total capacity, which is shown in the formula:

$$
x_{i}=\frac{C_{i}}{C_{f}+C_{w}+C_{s}} \times v(f, w, s)(i=f, w, s)
$$

where $C_{f}$ is the capacity of self-generation power plants, $C_{w}$ is the capacity of wind power station, $C_{s}$ is the capacity of photovoltaic power station.

\section{Shapley Value allocation strategy}

Shapley Value can be regarded as the expected value of the contributions made by the players in the cooperative game. Taking the benefits allocation of three generation power plants as an example, which is shown in the formula:

$$
\begin{aligned}
x_{f}= & \frac{2 !}{3 !} \times[v(f)]+\frac{1 !}{3 !} \times[v(f, \mathrm{w})-v(w)]+\frac{1 !}{3 !} \times[v(f, \mathrm{~s})-v(s)] \\
& +\frac{2 !}{3 !} \times[v(f, w, s)-v(w, s)]
\end{aligned}
$$

where $x_{f}$ is the benefits of self-generation power plants, $v(f), v(w), v(s)$ is respectively the benefits of self-generation power plants,wind power station and photovoltaic power station in their own way respectively. $v(f, w)$ is the cooperation benefits of self-generation power plants and wind power station, $v(f, \mathrm{~s})$ is the cooperation benefits of 
self-generation power plants and photovoltaic power station, $v(w, s)$ is the cooperation benefits of wind power station and photovoltaic power station, $v(f, w, s)$ is the cooperation benefits of three generation power plants. $x_{w}$ and $x_{s}$ can be calculated in the same way.

\section{Design of Generation Rights Trade Mode Between RENEWABle ENERGy AND SELF-GENERATION POWER Plants}

Based on the background of electric power system reform and the power generation characteristics of self-generation power plants and renewable energy, this paper designed the generation rights trade between renewable energy and self-generation power plants, which is shown below:

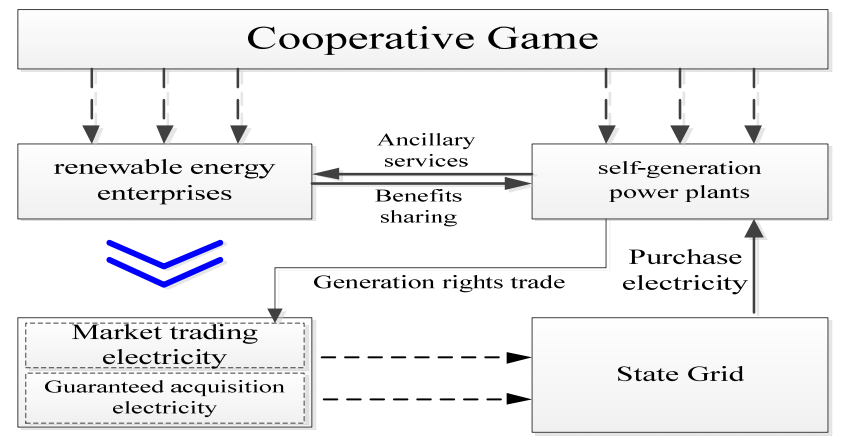

Fig. 1. Mode of generation rights trade between renewable energy and self-generation power plants based on Cooperative Game Theory
The mode of generation rights trade between renewable energy and self-generation power plants on the basis of cooperative game is defined as participants in the cooperation of renewable energy enterprises (mainly refers to wind power station and photovoltaic power station) and self-generation power plants reach a binding cooperation agreement, and share the benefits based on the optimization of the interests of the alliance according to the contribution of participants. The cooperative restraints include power generation space provided by self-generation power plants for renewable energy enterprises, ancillary service provided by self-generation power plants for renewable energy enterprises, power purchase from the State Grid for self-generation power plants and compensation provided by renewable energy enterprises for self-generation power plants, which is the sharing of the benefits ${ }^{[5-9]}$

\section{CASE ANALYSIS}

According to Cooperative Game Theory and relevant allocation strategy, this paper analyzes the benefits distribution of the three participants in the generation rights trade between renewable energy and self-generation power plants and verifies the feasibility of the generation rights trade mode. Taking Jinchang district as an example which is in Gansu Province, the specific parameters are shown in the following table.

TABLE I. BASIC DATA OF PARTICIPANTS

\begin{tabular}{|c|c|c|c|c|c|c|}
\hline Item & $\begin{array}{c}\text { Installed } \\
\text { capacity } \\
(\mathbf{M W})\end{array}$ & $\begin{array}{l}\text { Guaranteed } \\
\text { acquisition } \\
\text { hours }(\mathbf{h})\end{array}$ & $\begin{array}{c}\text { The minimum } \\
\text { acquisition } \\
\text { electricity }(\mathbf{G W h})\end{array}$ & Cost(yuan/kWh) & $\begin{array}{l}\text { On-grid tariff } \\
\text { (yuan/kWh) }\end{array}$ & $\begin{array}{l}\text { Unit benefit } \\
(\mathbf{y u a n} / \mathbf{k W h})\end{array}$ \\
\hline self-generation power plants & 300 & -- & - & 0.32 & -- & -0.32 \\
\hline wind power station & 150 & 500 & 75 & 0.044 & 0.56 & 0.516 \\
\hline photovoltaic power station & 200 & 400 & 80 & 0.1 & 0.8 & 0.7 \\
\hline
\end{tabular}

\section{A. Analysis of Pre-Cooperation Benefits}

In order to have a more intuitive analysis about the change of benefits brought by the mode of generation rights trade, only considered the guaranteed acquisition electricity of renewable energy. Meanwhile, self-generation power plants only generate power costs, so assuming that the benefits of self-generation power plants is negative before the cooperation, then the cost reduction of power generation is regarded as the increase of benefits after cooperation. Specific benefits are shown in the table below:

TABLE II. ANALYSIS OF PRE-COOPERATION BENEFITS

\begin{tabular}{|c|c|c|c|}
\hline Item & $\begin{array}{c}\text { Unit benefit } \\
(\mathbf{y u a n} / \mathbf{k W h})\end{array}$ & $\begin{array}{c}\text { electricity } \\
(\mathbf{G W h})\end{array}$ & $\begin{array}{c}\text { Total benefit } \\
(\mathbf{m i l l i o n})\end{array}$ \\
\hline $\begin{array}{c}\text { self-generation } \\
\text { power plants }\end{array}$ & -0.32 & 100 & -32 \\
\hline $\begin{array}{c}\text { wind power } \\
\text { station }\end{array}$ & 0.516 & 75 & 38.7 \\
\hline $\begin{array}{c}\text { photovoltaic } \\
\text { power station }\end{array}$ & 0.7 & 80 & 56 \\
\hline \multicolumn{2}{|c|}{ total } & 255 & 62.7 \\
\hline
\end{tabular}

\section{B. Analysis of Post-Cooperation Benefits}

Under the mode of generation rights trade, self-generation power plants reserve the minimum output to provide ancillary services for the renewable energy, assuming that the $40 \mathrm{GWh}$ generation space is replaced by the renewable energy generation, and the required amount electricity is purchased from State Grid; meanwhile, the benefits of renewable energy will be shared to self-generation power plants based on the response allocation strategy. Assuming that when the self-generation power plants form a "two bodies" coalition independently with the wind power enterprises or with the PV power enterprises alone, the self-generation power plants will give the output space to wind power enterprises or PV power enterprises which participated in the cooperative game; When the self-generation power plants form a "three bodies" coalition, they will respectively give $50 \%$ output space to wind power enterprises and PV power enterprises respectively at the same time. The benefits under different scales will be shown in the following table: 
TABLE III. ANALYSIS OF ALLIANCE BENEFITS BETWEEN SELF-GENERATION POWER PLANTS AND WIND POWER STATION

\begin{tabular}{|c|c|c|c|}
\hline \multirow{2}{*}{ Item } & $\begin{array}{c}\text { Unit benefit } \\
(\mathbf{y u a n} / \mathbf{k W h})\end{array}$ & $\begin{array}{c}\text { electricity } \\
(\mathbf{G W h})\end{array}$ & $\begin{array}{c}\text { Total benefit } \\
(\mathbf{m i l l i o n})\end{array}$ \\
\hline $\begin{array}{c}\text { self-generation } \\
\text { power plants }\end{array}$ & -0.32 & 60 & -37.6 \\
\cline { 2 - 3 } & -0.46 & 40 & 59.34 \\
\hline $\begin{array}{c}\text { wind power } \\
\text { station }\end{array}$ & 0.516 & 115 & 21.74 \\
\hline total & -- & 215 & \\
\hline
\end{tabular}

TABLE IV. ANALYSIS OF ALLIANCE BENEFITS BETWEEN SELF-GENERATION POWER PLANTS AND PHOTOVOLTAIC POWER STATION

\begin{tabular}{|c|c|c|c|}
\hline Item & $\begin{array}{c}\text { Unit benefit } \\
(\mathbf{y u a n} / \mathbf{k W h})\end{array}$ & $\begin{array}{c}\text { electricity } \\
(\mathbf{G W h})\end{array}$ & $\begin{array}{c}\text { Total benefit } \\
(\mathbf{m i l l i o n})\end{array}$ \\
\hline $\begin{array}{c}\text { self-generation } \\
\text { power plants }\end{array}$ & -0.32 & 60 & -37.6 \\
\cline { 2 - 3 } & -0.46 & 40 & 84 \\
\hline $\begin{array}{c}\text { photovoltaic } \\
\text { power station }\end{array}$ & 0.7 & 120 & 46.4 \\
\hline total & -- & 220 & \\
\hline
\end{tabular}

TABLE V. ANALYSIS OF ALLIANCE BENEFITS

\begin{tabular}{|c|c|c|c|}
\hline Item & $\begin{array}{c}\text { Unit benefit } \\
(\mathbf{y u a n} / \mathbf{k W h})\end{array}$ & $\begin{array}{c}\text { electricity } \\
(\mathbf{G W h})\end{array}$ & $\begin{array}{c}\text { Total benefit } \\
(\text { million })\end{array}$ \\
\hline $\begin{array}{c}\text { self-generation } \\
\text { power plants }\end{array}$ & -0.32 & 60 & -37.6 \\
\cline { 2 - 3 } $\begin{array}{c}\text { wind power } \\
\text { station }\end{array}$ & -0.46 & 40 & 49.02 \\
\hline $\begin{array}{c}\text { photovoltaic } \\
\text { power station }\end{array}$ & 0.516 & 95 & 70 \\
\hline total & 0.7 & 100 & 81.42 \\
\hline
\end{tabular}

In the mode of generation rights trade between renewable energy and self-generation power plants, the benefits of different scales are summarized as follows.
TABLE VI. THE GATHERING BENEFITS BETWEEN SELF-GENERATION POWER PLANTS AND RENEWABLE ENERGY ENTERPRISES

\begin{tabular}{|c|c|c|}
\hline Alliance & Scale & $\begin{array}{c}\text { benefits } \\
\text { (million) }\end{array}$ \\
\hline self-generation power plants & one & -32 \\
\hline wind power station & one & 38.7 \\
\hline $\begin{array}{c}\text { photovoltaic power station } \\
\text { self-generation power plants+ wind } \\
\text { power station }\end{array}$ & one & 56 \\
\hline $\begin{array}{c}\text { self-generation power plants } \\
\text { +photovoltaic power station }\end{array}$ & two & 46.4 \\
\hline $\begin{array}{c}\text { wind power station+ photovoltaic } \\
\text { power station }\end{array}$ & two & 94.7 \\
\hline $\begin{array}{c}\text { self-generation power plants+ wind } \\
\text { power station+ photovoltaic power } \\
\text { station }\end{array}$ & three & 81.42 \\
\hline
\end{tabular}

From the above table, it can be seen that there is a net income in the case of cooperative game after generation rights trade between self-generation power plants and renewable energy. By using the three kinds of allocation strategies, we distributed the benefits of "three bodies", the details are as follows:

TABLE VII. ANALYSIS OF BENEFITS UNDER DIFFERENT ALLOCATION STRATEGIES

\begin{tabular}{|c|c|c|c|}
\hline \multirow{2}{*}{$\begin{array}{l}\text { allocation } \\
\text { strategies }\end{array}$} & \multicolumn{3}{|c|}{ benefits (million) } \\
\hline & $\begin{array}{c}\text { self-generation } \\
\text { power plants }\end{array}$ & $\begin{array}{l}\text { wind power } \\
\text { station }\end{array}$ & $\begin{array}{l}\text { photovoltaic } \\
\text { power station }\end{array}$ \\
\hline $\begin{array}{c}\text { Equal allocation } \\
\text { strategy }\end{array}$ & 27.14 & 27.14 & 27.14 \\
\hline $\begin{array}{c}\text { Capacity allocation } \\
\text { strategy }\end{array}$ & 37.58 & 18.79 & 25.05 \\
\hline $\begin{array}{c}\text { Shapley Value } \\
\text { allocation strategy }\end{array}$ & -19.52 & 39.98 & 60.96 \\
\hline
\end{tabular}

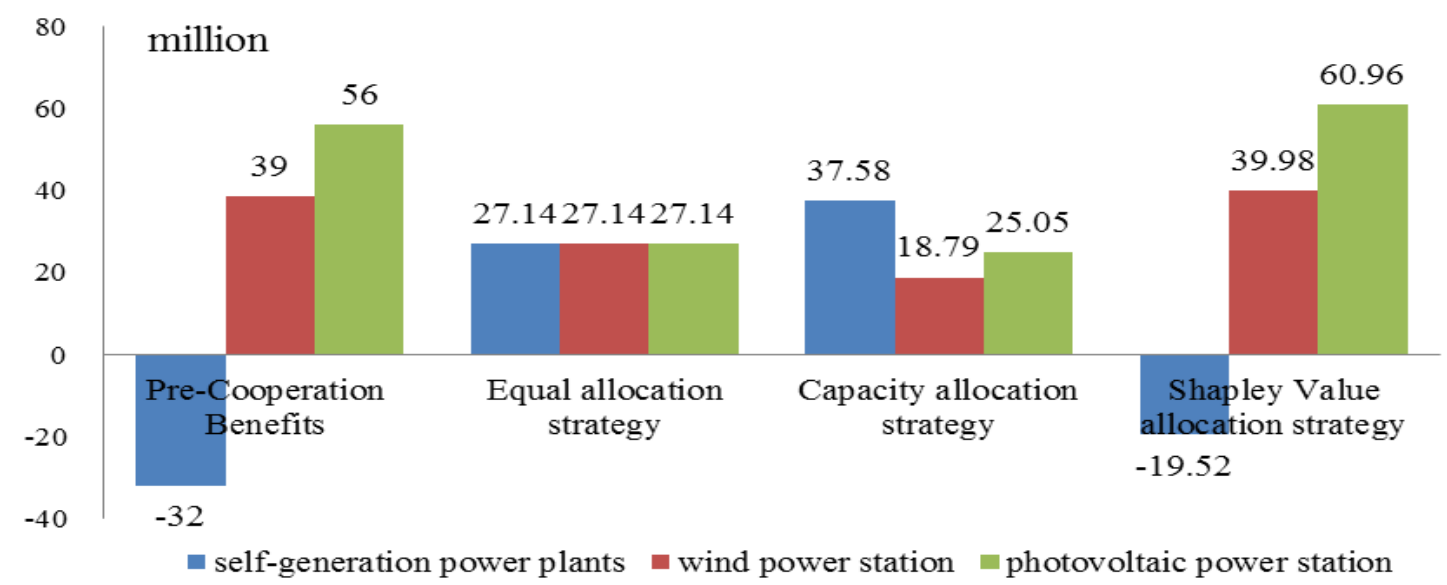

Fig. 2 Contrast of benefits under different allocation strategies

As can be seen from TABLE7 and Fig.2, the benefits of both wind power station and photovoltaic power station are less than their own, which does not conform to individual rationality, so wind power station and photovoltaic power station will not be willing to participate in the cooperative game under these two allocation strategies. While in the
Shapley Value allocation strategy, all the three are satisfied with individual rationality and the overall rationality of the cooperative game. So self-generation power plants, wind power station and photovoltaic power station are all inclined to participate in the cooperative game under the Shapley Value allocation strategy. 


\section{CONCLUSION}

Under the background of wind and photovoltaic curtailment severely, this paper designed the mode of generation rights trade between renewable energy and self-generation power plants based on Cooperative Game Theory and validated that all the three tend to participate in the cooperative game under the Shapley Value allocation strategy. This mode not only can raise the participants' enthusiasm to promote renewable energy consumption and alleviate the phenomenon of wind and photovoltaic curtailment, but also is conducive to the transformation of self-generation power plants. Therefore, this mode has certain feasibility and extension in the transition period of China's electric power market.

\section{ACKNOWLEDGMENT}

The work described in this paper was supported by research grant from science and technology projects of State Grid Electric Power Corporation in China.

\section{REFERENCES}

[1] ZHOU Jing, WANG Ke, WANG Weizhou, "Benefit Analysis and Application Discussion of Trading Mode with Self-owned Power Plant
Participating in Renewable Energy Consumption" Automation of Electric Power Systems, vol. 40, pp.145-150,2016.

[2] HUA Xia, LUO Fan, ZHANG Jianhua, "Feasibility Analysis of Trade Mode Promoting New Energy Consumption Based on Generation Rights of Self-generation Power Plants" Automation of Electric Power Systems, vol. 40, pp.200-205,2016.

[3] LI Yinghua, XING Mingde, LIU Jian, "Investigation and analysis on self-supply power plants in Northwest China", Energy Technology and Economic, vol. 22, pp. 12-15, 2012.

[4] DONG Baomin, WANG Yuntong, GUO Guixia, "Cooperative Game Theory" China Market Press, pp. 5-20,2008.

[5] YANG Huping, ZUO Shiwei, CHEN Huan, "Optimization of generation right transaction considering steady state voltage stability under carbon emission constraint”. Power System Technology, vol. 38, pp.3011-3015,2014.

[6] LIU Wenying, WEN Jing, XIE Chang, "Multi-objective optimal method considering wind power accommodation based source-load coordination" Proceedings of the CSEE, vol. 35,pp. 35-45,2015.

[7] ZHANG Xian, GENG Jian, PANG Bo, "Application and analysis of generation right trade in energy-saving and emission reduction" Automation of Electric Power Systems, vol.38, pp. 87-90, 2014.

[8] WU Yang, LIU Junyong, GAO Hongjun, et al, "Research on Power Generation Right Trading Between Wind Power and Thermal Power Based on Risky Decision-Making” Power System Technology, vol.40, pp. 833-839. 2016.

[9] BAO Hai, AI Dongping, YANG Yihan, et al, "Model of generation rights trade based on the forward and day-ahead markets" Power System Technology, vol. 36, pp. 264-270,2012. 